\begin{tabular}{|c|c|c|c|c|c|c|}
\hline \multirow{4}{*}{ Impact Factor: } & ISRA (India) & $=3.117$ & SIS (USA) & $=0.912$ & ICV (Poland) & $=6.630$ \\
\hline & ISI (Dubai, UAE & $=0.829$ & РИНЦ (Russia & $=\mathbf{0 . 1 5 6}$ & PIF (India) & $=1.940$ \\
\hline & GIF (Australia) & $=0.564$ & ESJI (KZ) & $=8.716$ & IBI (India) & $=4.260$ \\
\hline & JIF & $=1.500$ & SJIF (Morocco & $=\mathbf{5 . 6 6 7}$ & OAJI (USA) & $=0.350$ \\
\hline
\end{tabular}

\section{SOI: 1.1/TAS DOI: 10.15863/TAS International Scientific Journal Theoretical \& Applied Science}

\author{
p-ISSN: 2308-4944 (print) e-ISSN: 2409-0085 (online) \\ Year: $2019 \quad$ Issue: $04 \quad$ Volume: 72
}

Published: $24.04 .2019 \quad$ http://T-Science.org

SECTION 22. Policy. Innovations. Theory, practice and methods.
QR - Issue

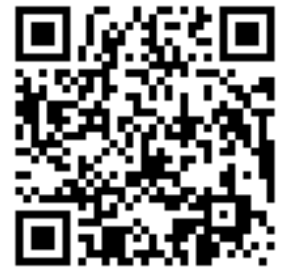

Dilshodbek Tursunboy ugli Komilov Master student of Andizhan State University, Republic of Uzbekistan

\title{
THE ROLE OF ADMINISTRATIVE REFORM IN THE SYSTEM OF CABINET OF MINISTERS IN UZBEKISTAN
}

Abstract: Article is devoted reforms in the area of execution government in independent years in Uzbekistan by the helping media materials, historical books and scientific literatures as well.

Key words: Uzbekistan, execution government, reforms, state, economy, organization.

Language: English

Citation: Komilov, D. T. (2019). The role of administrative reform in the system of cabinet of ministers in Uzbekistan. ISJ Theoretical \& Applied Science, 04 (72), 325-327.

Soi: http://s-o-i.org/1.1/TAS-04-72-38 Doi: crossef https://dx.doi.org/10.15863/TAS.2019.04.72.38

\section{Introduction.}

The state of Uzbekistan, with its role and capacities in the world community, has set itself the goal of building a just civil society based on a sociallyoriented free marketplace and a fair civil society that promotes human rights and freedoms. Many reforms have been carried out in this area, and the reforms are aimed not only to reform, but also to the welfare and prosperity of the people living there. Consequently, when the priority of human interests becomes the main criterion of the state power, President Shavkat Mirziyoev addressed to the Oliy Majlis of the Republic of Uzbekistan on December 22, 2017, on the basis of a clear criterion and procedure for the further perfection of the activity of the executive branch (Cabinet of Ministers) and lower government bodies in the country's administration has been approved. These criteria and procedures include:

\section{Methods of research.}

First of all, it is necessary to improve the performance of the executive branch, to introduce specific criteria and procedures for the use of personnel, material resources.

Secondly, it is necessary to clearly define the order of execution of the functions of the executive branch and their responsibilities.

Thirdly, it is necessary to reduce the administrative impact on the sectors of the economy and the use of market mechanisms. In other words, it is necessary to restrict the creation of business-linked businesses, develop market-specific mechanisms, and transfer certain functions of the state to the private sector.

Fourthly, it is necessary to gradually overestimate the centralized governance by improving the methods and methods that will ensure close cooperation between the representative authorities and executive authorities. There is a need to provide public services directly in lower levels, and to increase the financial and other capacities of local authorities. There is a need to streamline and simplify the existing procedures, introduce innovative forms of governance.

Fifth, it is necessary to reform the institute of public service and introduce mechanisms of effective anti-corruption. Today, life itself requires an effective system of forming a professional, fast and effective public service system, opening up a broader approach to innovative thinking, initiative, country-loyal staff [1, p.21].

Indeed, today we have been targeted at building a civil society by introducing the concept of "from a strong state to stronger society" to the development of the developed countries, whilst fully overseeing human rights and interests, creating a free and prosperous life. In this regard, it is the time of deepening democratic reforms and modernization of the country, primarily aimed at improving the state and society building. Further improvement of the role of executive power in reforming and modernizing the public administration system has become a necessity to develop a concept of administrative reform to regulate democratic reforms in a society. Based on this 


\begin{tabular}{|c|c|c|c|c|c|c|}
\hline \multirow{4}{*}{ Impact Factor: } & ISRA (India) & $=3.117$ & SIS (USA) & $=0.912$ & ICV (Poland) & $=6.630$ \\
\hline & ISI (Dubai, UAE & $=0.829$ & РИНЦ (Russia & $=0.156$ & PIF (India) & $=1.940$ \\
\hline & GIF (Australia) & $=0.564$ & ESJI (KZ) & $=8.716$ & IBI (India) & $=4.260$ \\
\hline & JIF & $=1.500$ & SJIF (Morocco & $=\mathbf{5 . 6 6 7}$ & OAJI (USA) & $=0.350$ \\
\hline
\end{tabular}

need, the Decree of the President of the Republic of Uzbekistan Shavkat Mirziyoev of 8 September 2017 "On Approval of the Concept of Administrative Reforms in the Republic of Uzbekistan" was adopted by the Decree \# PF - 5185 [2, p.3].

Consequently, the modernization of state power bodies has been step up in all spheres of life in order to liberalize all spheres of public life. The existing shortcomings in the public administration system do not allow adequate response to growing demands of the community, addressing the problems faced at the local level, accelerating the development of the economy and, as a consequence, the ongoing positive changes in the lives of people. In this regard, it is of particular importance to formulate a conceptual new concept of public administration through the successful implementation of the Concept of Administrative Reforms, which outlines the main directions.

Particular attention was paid to the sharp reduction of the direct intervention of the executive structures of the executive and administrative bodies of the executive branch to the functioning of the business structures in order to change the powers of regulating and distributing their management. In other words, adaptation of their powers to free market relations and market principles was taken to reduce the interference of the state into economic management. This led to the decentralization transition from centralization to governance, namely, the transition from the national level to the regional, district and city levels, and to the self-governing body, which was a form of governance, into the mahalla's citizens' gatherings [3, p.9].

At the same time, taking into account the priorities of the public interest on the basis of the ongoing reforms in the process of implementation of the Strategy of Action adopted by the Decree of the President of the Republic of Uzbekistan № PP-4947 on 7 February 2017 in five priority directions of further development of the country in 2017-2021 the results of the conversation show that the serious shortcomings preventing the full realization of the reforms are preserved. In particular, the creation of bases for the organization of the executive branch of the executive branch does not provide timely resolution of the problems faced in the development of the regions. The fact that the legal status of the executive authorities (ministries, state committees, agencies, committees, centers, inspections) is not clearly limited does not allow determining the exact role and the role of their role in the state apparatus. The country's public administration system is an integral part of its political, social, legal and administrative culture. Management culture is influenced by a number of historical, national, geographical, spiritual and other factors. Management culture is relatively stable and sensitive to public administration structures. Due to this, it is difficult to change the history of political (State) culture in a relatively short period of time [4, p.34].

Reform and modernization of public administration are carried out on the basis of the principles and requirements set out in the Constitution and the laws. The broader involvement of citizens in public administration, the ideas of democratic governance have been reflected in a number of international legal instruments. The directions of modernization of public administration are set out in the Action Strategy, which states: "... Decentralization of public administration, gradual reduction of government involvement in government regulation of economic regulation, increase of professional training, material and social welfare of civil servants, reforming the public service system;

introduction of modern mechanisms of publicprivate partnership aimed at increasing the effectiveness of mutually beneficial cooperation in the implementation of socio-political and socio-economic development of the country;

ensuring openness of public authorities, introducing modern forms of information on rights and freedoms and legitimate interests of individuals and legal entities;

Improving the "e-Government" system, improving the quality and effectiveness of public services, and enhancing the accessibility of the services by the population and business entities [5, p.87].

The goal of reform in the government of Uzbekistan is to ensure the well-being of the population [6, p.3]. As a result of the ongoing and ongoing reforms in this area, it is nowadays that government oversight of improving the living conditions of the people [7, p.2], creating a great deal of openness and transparency in the activities of public authorities in the creation of all conditions for their well - is being implemented. A number of work has been done to ensure the transparency of state power and governance bodies, based on the notion that "not public authorities [8, p.3], but public authorities should serve the public", with the opening of public reception centers, focus on improving [9, p.2].

Nizomulmulk, a senior clerk at the medieval Oriental Revival era in Malicshah's palace (10721092), cited the justice of the ruler in his book Siyasatna, saying: "... The king will receive the oppressors two days a week, be punished and heard directly by the words of the Lord. If the Gospel would invite the King to the Crown, listen to their words twice a week, and spread the news that the wrongdoers would be punished in the country, then they would not be frightened by fear of the consequences "[10, p.13].

\section{Conclusion.}

In conclusion, It is necessary to say today President Shavkat Mirziyayev's initiatives are being carried out by the Presidential Councils of the 


\begin{tabular}{|c|c|c|c|c|c|c|}
\hline \multirow{4}{*}{ Impact Factor: } & ISRA (India) & $=3.117$ & SIS (USA) & $=0.912$ & ICV (Poland) & $=6.630$ \\
\hline & ISI (Dubai, UAE & $=0.829$ & РИНЦ (Russia) & $=0.156$ & PIF (India) & $=1.940$ \\
\hline & GIF (Australia) & $=0.564$ & ESJI (KZ) & $=8.716$ & IBI (India) & $=4.260$ \\
\hline & JIF & $=1.500$ & SJIF (Morocco & $=5.667$ & OAJI (USA) & $=0.350$ \\
\hline
\end{tabular}

Republic of Uzbekistan in all regions of the Republic to hear about the challenges and problems of the 33 million people of Uzbekistan. In addition, the electronic communication service has been established and the Presidential Party is functioning. On the basis of the idea that "public institutions should serve the public, not the public," the focus is on improving the performance of public administration in order to increase the effectiveness of public services in the country, and administrative reform is being carried out. In turn, the goal of the administrative reform is to improve the public service delivery system and to elevate the public administration system to a new level, taking into account the interests of all segments of the population.

\section{References:}

1. (2018). Appeal to the President of the Republic of Uzbekistan Shavkat Mirziyoev to the Oliy Majlis. Tashkent: Uzbekistan.

2. (n.d.). The Decree of the President of the Republic of Uzbekistan No. UP-5185 // Publication No. 201 (6874)

3. Yunusov (2013). Leader + law + work style + Responsibilities Success in modern governance Andizhan.

4. (2017). Scientific-methodological manual on the study of the State Program on implementation of the Strategy of Action in the five priorities of development of the Republic of Uzbekistan for 2017-2021 at the Year of Communication and
Human Interest in Public Relations Tashkent2017.

5. (2011). Appendix 1 to the Decree of the President of the Republic of Uzbekistan dated February 7, 2017, N UP-4947, dated 28 February, 2011, No. 28 (6722) of the "Khalk Suzi" newspaper.

6. (2017, February 12). Halk Suzi newspaper.

7. (2017, February 9). Khalk Suzi newspaper.

8. (2017, February 18). Khalk Suzi newspaper.

9. (2017, February 24). Khalk Suzi newspaper.

10. (2017). Regulation.Politics (Siyar ul-muluk).Tashkent: New Generation. 